\title{
PEMBELAJARAN BAHASA INGGRIS \\ DI SEKOLAH DASAR
}

(Penelitian Etnografi di SDSN Pondok Kelapa 03 Pagi Jakarta Timur)

\author{
Iriany Kesuma Wijaya \\ STKIP YPUP \\ Jln. Andi Tonro no 17 Makasar \\ Irianykesumawijaya1959@gmail.com
}

\begin{abstract}
This study aims to gain a deep and comprehensive understanding of the process of learning English language learners in the class II SDSN Pondok Kelapa 03 Pagi Jakarta Timur by using a qualitative approach ethnographic method. The process involves the roles of teachers and learners. Teachers are able to create a good learning atmosphere that have a positive impact on student learning and therefore, the learning outcome become maximum. She also serves as director of activities, both individually and in groups. Learners will always feel safe because the teachers have always paid attention to students while they are learning independently. The approach based on assumptions about the nature of language how language learning is carried out. English learning is to develop English language skills contextually and acceptably. It is according to context, conditions and daily situation of the students. It is recommended that the result of the study needs to be integrated for the commonucation media which is appropriate to the needs of the students.
\end{abstract}

Keywords : English language learning, etnography, teacher as guidance

\begin{abstract}
ABSTRAK
Penelitian ini bertujuan untuk memperoleh pemahaman yang mendalam dan komprehensif tentang proses pembelajaran bahasa Inggris pada peserta didik kelas II di SDSN Pondok Kelapa 03 Pagi Jakarta Timur dengan menggunakan pendekatan kualitatif metode etnografi. Proses pembelajaran melibatkan peran guru dan peserta didik. Guru mampu menciptakan suasana pembelajaran dengan baik sehingga berdampak positif pada proses belajar siswa dan akhirnya hasil belajar menjadi maksimal. Guru juga berperan sebagai pengarah kegiatan baik secara individu maupun secara berkelompok. Peserta didik akan selalu merasa aman dan diperhatikan karena guru selalu berada diantara peserta didik walaupun mereka belajar secara mandiri. Pendekatan mengacu pada asumsi-asumsi mengenai hakikat bahasa bagaimana pembelajaran bahasa dilakukan. Pembelajaran bahasa Inggris adalah mengembangkan kemampuan berbahasa Inggris secara kontekstual dan berterima sesuai dengan konteks serta kondisi dan situasi keseharian peserta didik. Hal ini untuk menghasilkan bentuk pembelajaran bahasa Inggris yang lebih menyentuh kebutuhan berbahasa peserta didik. Temuan tersebut perlu diintegrasikan sedemikian rupa sehingga menghasilkan kegiatan belajar yang menekankan pada aspek bagaimana bahasa Inggris digunakan sebagai alat komunikasi yang sesuai dengan kebutuhan peserta didik.
\end{abstract}

Kata kunci: Pembelajaran bahasa Inggris, etnografi, guru pengarah kegiatan

Sekolah Dasar Negeri Pondok salah satu bentuk pendidikan dasar di Kelapa 03 Pagi Jakarta Timur, sebagai wilayah Negara Kesatuan Republik 
Indonesia, merupakan Sekolah Standar Nasional (SSN) sejak tahun 2008. Sekolah Dasar ini terletak di Jalan Tipar, di pertigaan dari Jalan Raya Pondok Kelapa Kota Administrasi Jakarta Timur Provinsi Daerah Khusus Ibukota Jakarta. Sebagai Sekolah Standar Nasional (SSN) Sekolah Dasar ini sudah memasukkan pelajaran bahasa Inggris pada seluruh tingkatan, atau kelas sejak tahun 2008. Peserta didik dari kelas I sampai kelas VI mendapatkan pelajaran bahasa Inggris sebagai muatan lokal (mulok).

Hal ini disebabkan oleh komunikasi antarbangsa memerlukan bahasa Inggris sebagai bahasa internasional, sehingga dalam pendidikan di Indonesia kemampuan berbahasa Inggris merupakan salah satu keterampilan yang harus dikuasai oleh peserta didik sejak awal. Dalam hal ini, pembelajaran bahasa Inggris diarahkan pada empat keterampilan di dalam bahasa Inggris antara lain: kemampuan mendengar (listening), berbicara (speaking), membaca (reading), dan kemampuan menulis (writing). Saat ini untuk di sekolah sekolah dasar, pelajaran bahasa Inggris masih diajarkan secara include dalam satu kesatuan tema lalu langsung diajarkan 4 keterampilan tersebut, sehingga untuk mengetahui penguasaan keterampilan tersebut dapat dilihat sebagai hasil pembelajaran peserta didik dalam pelajaran bahasa Inggris.

Brown (1994: 89) mengatakan pembelajaran sering dianggap sebagai terjemahan dari istilah "instructional" adalah proses interaksi peserta didik dengan pendidik dan sumber belajar pada suatu lingkungan belajar. Pembelajaran dijelaskan oleh Gagne dan Briggs dalam Brown, sebagai upaya orang yang tujuannya membantu orang belajar. Oleh karena itu ada lima asumsi yang mendukung pembelajaran, yaitu (1) pembelajaran mesti direncanakan agar memperlancar belajar peserta didik, (2) baik fase pendek maupun fase jangka panjang dimasukkan dalam rancangan pembelajaran, perencanaan pembelajaran hendaknya tidak asal-asalan dan tidak semata-mata menyediakan lingkungan asuh saja, (4) usaha pembelajaran mesti dirancang dengan ancangan sistem, dan (5) pembelajaran harus dikembangkan berdasarkan pengetahuan tentang bagaimana orang itu belajar.

Pada bagian lain, Uno (2007:54) menyatakan bahwa pembelajaran dapat diartikan sebagai suatu proses interaksi antara peserta belajar dengan pengajar/ instruktur dan atau sumber belajar pada suatu ingkungan belajar untuk mencapai tujuan belajar tertentu. Di sini terlihat bahwa pembelajaran adalah proses 
interaksi antara pesertadidik dengan lingkunganya sehingga menjadi perubahan prilaku kearah yang Iebih baik. Dalam proses pembelajaran, prinsip utamanya adalah adanya proses keterlibatan seluruh atau sebagaian besar potensi diri siswa dan kebermaknaanya bagi diri dan kehidupannya saat ini dan masa yang akan datang.

Lebih lanjut Gagne dan Briggs dalam Brown (1994: 9-10) menjelaskan bahwa ada beberapa ciri pembelajaran, yaitu (1) menarik perhatian agar peserta didik siap menerima pelajaran, (2) memberitahukan tujuan pelajaran, (3) merangsang timbulnya ingatan atas ajaran sebelumnya, (4) presentasi bahan ajaran dan alat bantu belajar (5) memberikan bimbingan belajar, (6) membangkitkan timbulnya unjuk kerja dalam belajar, (7) memberikan umpan balik, (8) menilai unjuk kerja, dan (9) memperkuat retensi dan transfer belajar.

Bahasa Inggris di Indonesia secara umum diajarkan sebagai bahasa asing. Istilah 'bahasa asing' dalam bidang pengajaran bahasa berbeda dengan 'bahasa kedua'. Bahasa asing adalah bahasa yang yang tidak digunakan sebagai alat komunikasi di negara tertentu di mana bahasa tersebut diajarkan. Sementara bahasa kedua adalah bahasa yang bukan bahasa utama namun menjadi salah satu bahasa yang digunakan secara umum di suatu negara. Sementara Bahasa asing biasanya diajarkan sebagai salah satu mata pelajaran di sekolah dengan tujuan berkomunikasi dasar serta menguasai 4 skill berbahasa (menyimak, membaca, menulis, berbicara) dalam bahasa tersebut dalam batasan tertentu.

Sementara itu Hapsari (2012) menyatakan pengajaran bahasa Inggris di Indonesia untuk siswa SD berlandaskan SK Menteri Pendidikan dan Kebudayaan No. 060/U/1993 tanggal 25 Februari tentang dimungkinkannya program bahasa Inggris sebagai mata pelajaran muatan local SD, dan dapat dimulai pada kelas 4 SD (depdiknas). Kebijakan ini diambil karena adanya kebutuhan untuk berpartisipasi dalam era globalisasi. Dalam perkembangannya bahasa Inggris yang awalnya adalah mata pelajaran muatan lokal pilihan menjadi mata pelajaran muatan lokal wajib di beberapa daerah. Lebih lanjut pelajaran bahasa Inggris yang pada mulanya dimulai pada kelas 4 SD dimulai pada kelas 1,2 dan 3.

Terkait dengan fokus penelitian etnografi, Johnson (2000: 12-13) mengemukakan bahwa "there are two general focuses of ethnografi study that particularly relevant to the field of second language acquisition and teaching. These are educationally communication." Artinya, studi etnografi terdapat dua fokus umum, studi etnografi yang secara khusus 
relevan dengan bidang pemerolehan dan pembelajaran bahasa (kedua), yakni etnografi pendidikan dan etnografi komunikasi. Johnson (2000: 12-13) menambahkan tentang definisi etnografi pendidikan yaitu sebagai studi tentang suatu atau semua proses pendidikan, apakah berhubungan dengan sekolah atau tidak. Dia juga mendefinisikan etnografi adalah sekolah sebagai studi tentang proses pendidikan dan lingkungan pendidikan, serta proses enkulturatif yang berhubungan dengan sekolah dan persekolahan internasional, termasuk aspek-aspek sekolah yangberhubungan dengan kehidupan peer groups.

Creswell (2008: 473) menjelaskan bahwa etnografi adalah prosedur penelitian kualitatif untuk mendeskripsikan, menganalisis dan menginterpretasikan suatu kelompok berkaitan dengan kultur mengenai pola tindakan, keyakinan dan bahasa. Pendekatan kualitatif dipilih karena penelitian etnografi dapat dilakukan dengan pengamatan berperan serta (participation observation). Penelitian etnografi memiliki karakteristik sebagai berikut: (1) sumber data diperoleh dari latar alami, (2) peneliti adalah instrumen kunci, (3) laporannya sangat deskriptif, (4) analisisnya bersifat induktif, (5) verifikasi data dilakukan melalui triangulasi, (6) partisipan dilakukan sejajar dengan peneliti, (7) sampelnya bersifat purposive,
(8) desain penelitiannya berkembang di lapangan.

Hasil penelitian relevan dengan masalah yang dibahas pernah dilakukan oleh Juanda pada tahun 2010 mengadakan penelitian yang berjudul: "Pembelajaran Keaksaraan Fungsional Orang Dewasa dan Faktor Sosial Budaya (Penelitian Etnografi di Sulsel)" Suatu Disertasi yang diajukan untuk memenuhi sebagai persyaratan dalam mendapatkan gelar Doktor. Penelitiannya menerapkan metode kualitatif dengan pendekatan etnografi. Penelitian ini mengelompokkan beberapa aspek, yaitu (1) tema budaya, (2) faktor sosial budaya dalam pembelajaran keaksaraan fungsional, dan (3) faktorfaktor yang mempengaruhi proses belajar mengajar berjalan efektif. Berkait dengan pengelompokan yang dilakukan, penelitian ini lebih berfokus pada pemberantasan buta aksara melalui pembelajaran. Untuk itu, penelitian yang berkait dengan pembelajaran bahasa Inggris dengan fokus yang lain perlu dilakukan.

Penelitian ini bertujuan untuk memperoleh pemahaman yang mendalam dan komprehensif tentang: (1) bagaimana proses pembelajaran bahasa Ingggris, (2) pendekatan dan metode pembelajaran bahasa Inggris, (3) peran guru sebagai sumber dan alat bantu belajar dalam pembelajaran bahasa Inggris di SDSN Pondok Kelapa 03 Pagi Jakarta Timur. 
Penelitian ini menggunakan pendekatan kualitatif metode etnografi. Metode tersebut digunakan untuk menjelaskan aspek-aspek (1) proses pembelajaran bahasa Ingggris, pendekatan dan metode pembelajaran bahasa Inggris, (3) peran guru sebagai sumber dan alat bantu belajar dalam pembelajaran bahasa Inggris di SDSN Pondok Kelapa 03 Pagi

Teknik yang digunakan untuk mengumpulkan data dalam penelitian ini adalah (1) observasi, (2) wawancara, (3) kajian dokumen dan rekaman. Prosedur analisis data dilakukan dengan cara (1) analisis domain, (2) analisis taksonomi, (3) analisis komponen, (4) anaalisis tema budaya. Pemeriksaan keabsahan data dalam penelitian dilakukan dengan cara credibility, transferability, dependability, dan confirmability.

Proses pembelajaran bahasa Inggris di SDSN Pondok Kelapa 03 Pagi Jakarta Timur, di awali dengan memotivasi peserta didik dengan cara bercerita yang dilakukan oleh guru atau salah seorang peserta didik di depan kelas. Kegiatan inti merupakan proses dan pengalaman belajar di dalam maupun di luar kelas , dan dengan kegiatan akhir dilakukan untuk merefleksi kegiatan yang sudah dilakukan peserta didik

Kegiatan awal pembelajaran dapat dilihat dan diketahui oleh peneliti dari hasil pengamatan dan wawancara dengan informan bahwa tahap awal pembelajaran, peserta didik memberi salam kepada guru kemudian guru merespon peserta didik, setelah itu dilakukan doa bersama, dan yang terakhir mengecek kehadiran peserta didik. Pada awal pembelajaran dimulai dengan cerita lucu atau guessing game berupa tebakan sederhana yang dilakukan oleh guru, atau menyuruh salah seorang peserta didik untuk bercerita dalam bahasa Inggris di depan kelas. Kegiatan seperti ini dilakukan untuk menumbuhkan motivasi peserta didik agar belajar lebih giat sehingga mampu berkomunikasi bahasa Inggris dengan baik. Namun kegiatan ini tidak selalu dilakukan guru pada setiap awal pembelajaran, ada kalanya guru memotivasi peserta didik dengan cara memberi nasehat kepada peserta didik.

Kegiatan inti pembelajaran merupakan pelaksanaan pembelajaran yang sesungguhnya, di mana guru dan peserta didik berinteraksi dalam pengalaman belajar yang dilakukan di dalam maupun di luar kelas. Tahap ini dimulai dengan menginformasikan peserta didik tentang topik dan tujuan pembelajaran yang akan dicapai. Kemudian membahas materi pelajaran secara klasikal, mendiskusikan pokok bahasan secara kelompok, dan meminta peserta didik memberi solusi pada pokok bahasan secara individual. Hal ini dilakukan untuk mengetahui sejauh mana 
peserta didik memahami pokok bahasan yang sedang dibelajarkan. Pada proses pembelajaran berlangsung sekaligus dilakukan evaluasi, karena penilaian pada pembelajaran bahasa Inggris dilakukan bukan hanya pada akhir proses pembelajaran saja, tetapi juga dilakukan pada saat proses pembelajaran berlangsung yang disebut penilaian autentik.

Kegiatan akhir pembelajaran merupakan kegiatan merefleksi dan mengevaluasi pengetahuan peserta didik tentang pokok bahasan yang baru saja dibelajarkan secara keseluruhan. Kegiatan ini berupa umpan balik dari peserta didik, hal ini dapat dilihat ketika peserta didik melakukan dan merespon pembelajaran dengan tindakan nyata seperti, mampu menjawab pertanyaan dan berbicara dalam bahasa Inggris dan menunjukkan hasil karya berupa tulisan atau karangan dalam bahasa Inggris. Data tentang prosedur ini dapat ditemukan pada setiap aktivitas pembelajaran yang ada pada setiap lampiran pengamatan kegiatan kelas.

Kegiatan pembelajaran tidak hanya dilakukan di dalam kelas, tetapi juga dilakukan di luar kelas, seperti: diruang laboratorium bahasa, teras sekolah atau taman dan lingkungan sekolah.

Metode mengajar yang dipakai atau dipraktikkan oleh guru adalah metode SAS yaitu Struktural Analisis dan Sintetik. Pada SAS, peserta didik dilatih mengetahui kosa kata dengan bantuan gambar dan mendengar dari pelafalan dari guru (proses struktural). Kata tersebut lalu dianalisis menjadi suku kata, huruf-huruf / sesuai dengan pelafalannya (proses analitik). Langkah terakhir adalah menggabungkan kembali huruf-huruf menjadi suku kata, suku kata menjadi kata, dan kata-kata menjadi kalimat (proses sintetik).

Berdasarkan pengamatan peneliti, dengan menggunakan metode SAS guru tidak menemui kesulitan di dalam mentransfer materi kepada peserta didik. Ketika ini terjadi, peserta didik akan merasa tertarik untuk mengungkapkan apa yang ada dalam pikirannya dalam bahasa Inggris (target) karena mereka termotivasi dan tidak terikat pada aturan tata bahasa. Biasanya, dalam kegiatan ini akan terlihat adanya paksaan secara langsung kepada peserta didik untuk mengetahui beberapa kata yang belum dikuasai oleh peserta didik, tentu hal ini sangat memberatkan karena banyaknya jenis atau pola kalimat yang mesti di hafal. Hal ini karena adanya ketakutan akan membuat kesalahan kalimat atau ujaran yang benar sesuai dengan pola kalimat yang dianjurkan. Tetapi fakta yang terjadi, justru peserta didik mampu mengungkapkan kalimat dalam bahasa Inggris secara otomatis atau natural.

Hasil penelitian menunjukkan bahwa pembelajaran bahasa Inggris 
dengan metode SAS di SDSN Pondok Kelapa 03 Pagi Jakarta Timur, dilakukan dengan penerapan strategi kontekstual menggunakan metode SAS bagi peserta didik kelas rendah yaitu Struktural Analisis dan Sintetik. Pada SAS, peserta didik dilatih mengetahui kosa kata dengan bantuan gambar dan mendengar dari pelafalan dari guru (proses struktural). Kata tersebut lalu dianalisis menjadi suku kata, huruf-huruf sesuai dengan pelafalannya (proses analitik). Langkah terakhir adalah menggabungkan kembali huruf-huruf menjadi suku kata, suku kata menjadi kata, dan kata-kata menjadi kalimat (proses sintetik).

Strategi pembelajaran menekankan keterlibatan peserta didik untuk mengkaitkan materi pembelajaran yang dipelajari dan menghubungkannya dengan situasi kehidupan nyata sehingga mendorong peserta didik untuk mampu menerapkannya dalam kehidupan atau lingkungan mereka sehari-hari.

Peran guru di SDSN Pondok Kelapa 03 pagi dalam pembelajaran bahasa Inggris adalah sebagai perancang atau sumber belajar, motivator, fasilitator, pembimbing, model, pengarah, evaluator dan partner (mitra belajar) peserta didik.

Pembelajaran konstektual menolong guru mengkaitkan materi pelajaran dengan situasi dunia nyata peserta didik, dan memotivasi peserta didik untuk membuat hubungan antara pengetahuan yang diperoleh dan aplikasinya dalam kehidupan mereka sebagai anggota keluarga, masyarakat, dan pekerjaan.

Dalam pandangan pembelajaran modern peserta didik maupun guru merupakan subjek pembelajaran. Dalam hal ini peserta didik tidak lagi dianggap sebagai objek belajar dan guru tidak lagi dianggap sebagai sumber informasi, tetapi keduanya berkolaborasi dalam proses interaksi belajar mengajar di kelas untuk mencapai tujuan yang ditetapkan. Peran peserta didik seperti dikemukakan di atas dapat disimak dalam pendapat Sanjaya bahwa peran peserta didik dalam pembelajaran kontekstual yaitu; (1) Peserta didik dipandang sebagai individu yang sedang berkembang. Kemampuan belajar peserta didik akan sangat ditentukan oleh tingkat perkembangan dan pengalaman mereka. (2) Setiap peserta didik memiliki kecenderungan belajar hal-hal yang baru dan penuh tantangan. Oleh karena itu belajar bagi mereka adalah mencoba memecahkan setiap persoalan yang menantang. (3) Belajar bagi mereka, proses mencari keterkaitan atau keterhubungan antara hal-hal yang baru dengan hal-hal yang sudah diketahui. (4) Belajar bagi peserta didik, proses menyempurnakan skema yang telah ada (asimilasi) atau proses pembentukan skema baru 
(akomodasi). Dengan demikian dalam proses pembelajaran, peserta didik sebagai titik sentral belajar, lebih aktif mencari dan memecahkan permasalahan belajar, dan tugas guru membantu kesulitan peserta didik yang mendapat kendala, dan kesulitan dalam memahami dan memecahkan permasalahan.

Mengingat keterbatasan waktu yang peneliti miliki, masih terdapat beberapa aspek yang belum tersentuh dalam penelitian ini, antara lain kegiatan ekstra kurikuler. Hal ini karena pelaksanaan ekstra kurikuler memerlukan waktu di luar jam KBM dan memerlukan waktu yang banyak mengingat ekstra kurikuler di sekolah ini cukup banyak.

Dari uraian di atas dapat disimpulkan bahwa proses pembelajaran bahasa Inggris di kelas II SDSN Pondok Kelapa 03 Pagi Jakarta Timur melibatkan peran guru dan peserta didik. Guru mampu menciptakan suasana pembelajaran dengan baik sehingga berdampak positif pada proses belajar siswa dan akhirnya hasil belajar menjadi maksimal. Guru juga berperan sebagai pengarah kegiatan baik secara individu maupun secara berkelompok. Peserta didik akan selalu merasa aman dan di perhatikan karena guru selalu berada diantara peserta didik walaupun mereka belajar secara mandiri. Sebagai penilai kemajuan prestasi belajar peserta didik berdampak pada rasa dihargai pada diri peserta didik dan hal ini akan memotivasi peserta didik untuk terus berkompetisi dan bertanggungjawab pada proses belajar dirinya. Guru sebagai fasilitator dan nara sumber pada materimateri baru bagi peserta didik akan menghasilkan rasa terfasilitasi dan menerima kebutuhan tiap individu peserta didik yang berbeda-beda.

\section{DAFTAR PUSTAKA}

Brown, H. Douglas, Principles of Language Learning and Teaching, New Jersey: Prentice Hall Regents, 2007.

Creswell, John, Educational Research: Planning, Conducting, and Evaluating Quantitative and Qualitative Research, Third Edition, Upper Saddle River, New Jersey: Pearson Merrill Prentice Hall, 2008.

E, Mulyasa, Menjadi Guru Profesional. Bandung: Rosdakarya 2009.

Johnson, Donna M., Approaches to Research in Second Language Learning, New York: Longman, 2000.

Johnson, Elaine B., Contextual Teaching and Learning: Menjadikan Belajar Mengajar Mengasyikan dan Bermakna diterjemahkan oleh Chaedar Alwasilah. Bandung: MCL 2012.

Mantja, W., Etnografi; Disain Penelitian Kualitatif dan Manajemen Pendidikan, Malang" Wineka Media, 2005. 
Richards, Jack C. dan Willy A. Renandya, Methodology Language Teaching: An Anthology of Current Practice New York: Cambridge University Press, 2002

Sanjaya, Wina "Strategi Pembelajaran Berorientasi standar Proses Pendidikan” Jakarta-Kencana 2008.
Sukmadinata, Nana Syaodih, Pengembangan Kurikulum Teori dan Praktek. Bandung: Rosdakarya 2014.

Suyono dan Hariyanto, Belajar dan Pembelajaran.

Bandung: Rosdakarya 2014.

Uno, Hamzah B. Profesi Kependidikan, Jakarta: Bumi Aksara, 2007. 